\title{
Large-Scale Synthesis of High-Quality Ultralong Copper Nanowires
}

Yu Chang, Mei Ling Lye, and Hua Chun Zeng*

Department of Chemical and Biomolecular Engineering, Faculty of Engineering

National University of Singapore, 10 Kent Ridge Crescent, Singapore 119260

\section{Supporting Information 1}

Experimental conditions for selected samples in this work:

\begin{tabular}{|c|c|c|c|c|c|c|c|c|c|}
\hline \multirow{2}{*}{ Expt. } & \multicolumn{2}{|c|}{$\mathrm{NaOH}$ aqueous solution } & \multicolumn{2}{|c|}{$\mathrm{Cu}\left(\mathrm{NO}_{3}\right)_{2}$ aqueous solution } & \multirow{2}{*}{$\begin{array}{l}\text { Volume of } \\
\text { EDA }(\mathrm{mL})\end{array}$} & \multirow{2}{*}{$\begin{array}{c}\text { Volume of } \\
\mathrm{N}_{2} \mathrm{H}_{4}(35 \mathrm{wt} \%) \\
\text { (uL) }\end{array}$} & \multirow{2}{*}{$\begin{array}{l}\text { Temperature } \\
\left({ }^{\circ} \mathrm{C}\right)\end{array}$} & \multirow{2}{*}{$\begin{array}{l}\text { Time } \\
\text { (h) }\end{array}$} & \multirow{2}{*}{$\begin{array}{c}\text { EDA: } \mathrm{OH}^{-}: \mathrm{Cu}^{2+}: \mathrm{N}_{2} \mathrm{H}_{4} \\
\text { Molar ratio }\end{array}$} \\
\hline & $\begin{array}{c}\text { Volume } \\
(\mathrm{mL})\end{array}$ & $\begin{array}{c}\text { Concentration } \\
(\mathrm{Mol} / \mathrm{L})\end{array}$ & $\begin{array}{c}\text { Volume } \\
(\mathrm{mL})\end{array}$ & $\begin{array}{c}\text { Concentration } \\
(\mathrm{Mol} / \mathrm{L})\end{array}$ & & & & & \\
\hline $\mathrm{A} 1$ & 20 & 15 & 1.0 & 0.10 & 0.15 & 25.0 & 60 & 1 & $22.39: 3000: 1.0: 2.76$ \\
\hline A2 & 20 & 15 & 1.0 & 0.10 & 0.125 & 25.0 & 60 & 1 & $18.66: 3000: 1.0: 2.76$ \\
\hline A3 & 20 & 15 & 1.0 & 0.10 & 0.10 & 25.0 & 60 & 1 & $14.93: 3000: 1.0: 2.76$ \\
\hline A4 & 30 & 7.0 & 1.0 & 0.10 & 0.50 & 25.0 & 60 & 1 & $74.64: 2100: 1.0: 2.76$ \\
\hline A5 & 30 & 3.5 & 1.0 & 0.10 & 0.50 & 25.0 & 60 & 2 & $74.64: 1050: 1.0: 2.76$ \\
\hline B1 & 20 & 15 & 1.0 & 0.10 & 2.00 & 25.0 & 60 & 1.5 & $298.56: 3000: 1.0: 2.76$ \\
\hline B2 & 20 & 15 & 1.0 & 0.10 & 1.00 & 25.0 & 60 & 1 & $149.28: 3000: 1.0: 2.76$ \\
\hline B3 & 20 & 15 & 1.0 & 0.10 & 0.50 & 25.0 & 60 & 1 & $74.64: 3000: 1.0: 2.76$ \\
\hline B4 & 20 & 15 & 1.0 & 0.10 & 0.30 & 25.0 & 60 & 1 & $44.79: 3000: 1.0: 2.76$ \\
\hline B5 & 20 & 15 & 1.0 & 0.10 & 0.20 & 25.0 & 60 & 1 & $29.86: 3000: 1.0: 2.76$ \\
\hline B6 & 20 & 15 & 1.0 & 0.10 & 0.075 & 25.0 & 60 & 1 & $11.20: 3000: 1.0: 2.76$ \\
\hline C1 & 30 & 7.0 & 1.0 & 0.10 & 0.50 & 25.0 & 100 & 1 & $74.64: 2100: 1.0: 2.76$ \\
\hline $\mathrm{C} 2$ & 30 & 7.0 & 1.0 & 0.10 & 0.50 & 30.0 & 55 & 4 & $74.64: 2100: 1.0: 3.32$ \\
\hline C3 & 30 & 7.0 & 1.0 & 0.10 & 0.50 & 60.0 & 50 & 1.5 & $74.64: 2100: 1.0: 6.64$ \\
\hline D1 & 30 & 7.0 & 1.0 & 0.10 & 0.50 & 25.0 & 60 & 0.5 & $74.64: 2100: 1.0: 2.76$ \\
\hline D2 & 30 & 7.0 & 1.0 & 0.10 & 0.50 & 25.0 & 60 & 0.75 & $74.64: 2100: 1.0: 2.76$ \\
\hline D3 & 30 & 7.0 & 1.0 & 0.10 & 0.50 & 25.0 & 60 & 3 & $74.64: 2100: 1.0: 2.76$ \\
\hline D4 & 30 & 7.0 & 1.0 & 0.10 & 0.50 & 25.0 & 60 & 4 & $74.64: 2100: 1.0: 2.76$ \\
\hline D5 & 30 & 7.0 & 1.0 & 0.10 & 0.50 & 25.0 & 60 & 13 & $74.64: 2100: 1.0: 2.76$ \\
\hline E1 & 30 & 7.0 & 0.50 & 0.10 & 0.35 & 35.0 & 60 & 1 & $104.50: 4200: 1.0: 7.74$ \\
\hline E2 & 30 & 7.0 & 0.50 & 0.10 & 0.30 & 35.0 & 60 & 1 & $89.57: 4200: 1.0: 7.74$ \\
\hline E3 & 30 & 7.0 & 0.50 & 0.10 & 0.20 & 35.0 & 60 & 1 & $59.71: 4200: 1.0: 7.74$ \\
\hline
\end{tabular}

Notes:

1) The experiments are divided into different series. The parameters investigated in each set are indicated in bold font.

2) Experimental conditions of Figure 1B (main text): Expt. A1.

Experimental conditions of Figure 1C and 1D (main text): Expt. A4.

Experimental conditions of Figure 2A, 2B, and 2D (main text): Expt. A4.

Experimental conditions of Figure 3B (main text): Expt. B2.

Experimental conditions of Figure 4A (main text): Expt. A1. 
Experimental Example:

Color changing point at 30-45 min (Expt. A4; Two different experiments were carried out for two different reaction times. The photos were taken at room temperature after each experiment.):

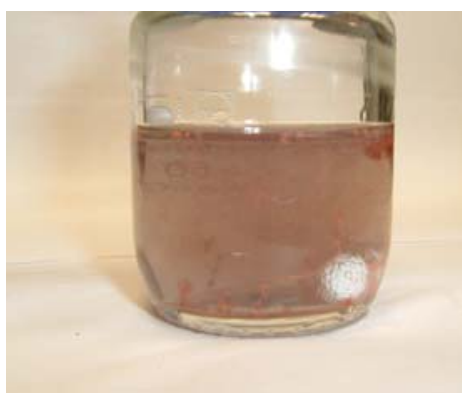

After $30 \mathrm{~min}$ at $60^{\circ} \mathrm{C}$

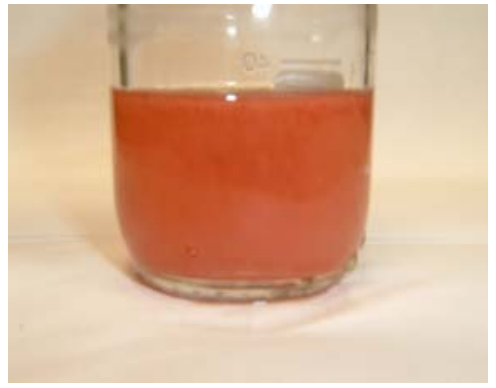

After $45 \mathrm{~min}$ at $60^{\circ} \mathrm{C}$

Unlike those shown in Figure 1A (main text, Expt. A1), the Cu nanowires shown here are in a lower density solution (Expt. A4) and floating/lifting ability of solution is thus lower. However, formation of cake-like $\mathrm{Cu}$ nanowires will also be observed with a longer process time without magnetic stirring. 


\section{Supporting Information 2}

The [001] zone diffraction spots of Cu nanowires:

In addition to the commonly observed [110] zone spots (Figure 2D, main text), [001] zone diffraction spots have also been observed. This TEM/SAED observation once again confirms the growth directions of our Cu nanowires are indeed along $\langle 110\rangle$.
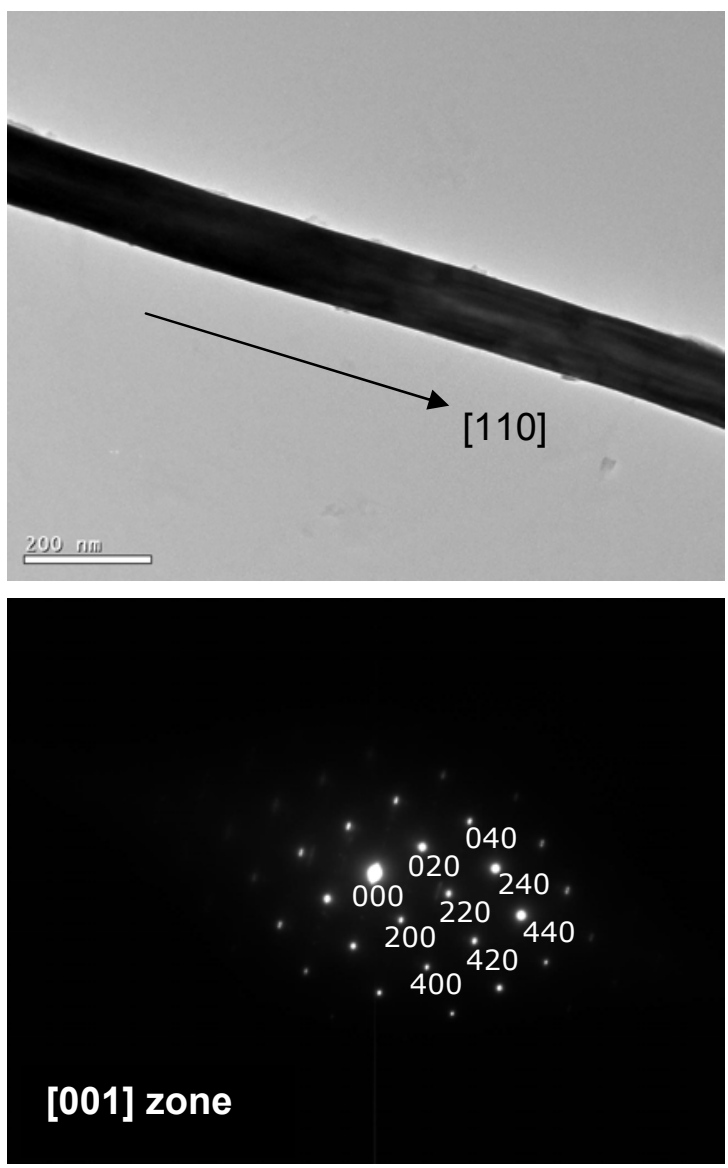


\section{Supporting Information 3}

Representative XRD patterns of some selected copper metal products:

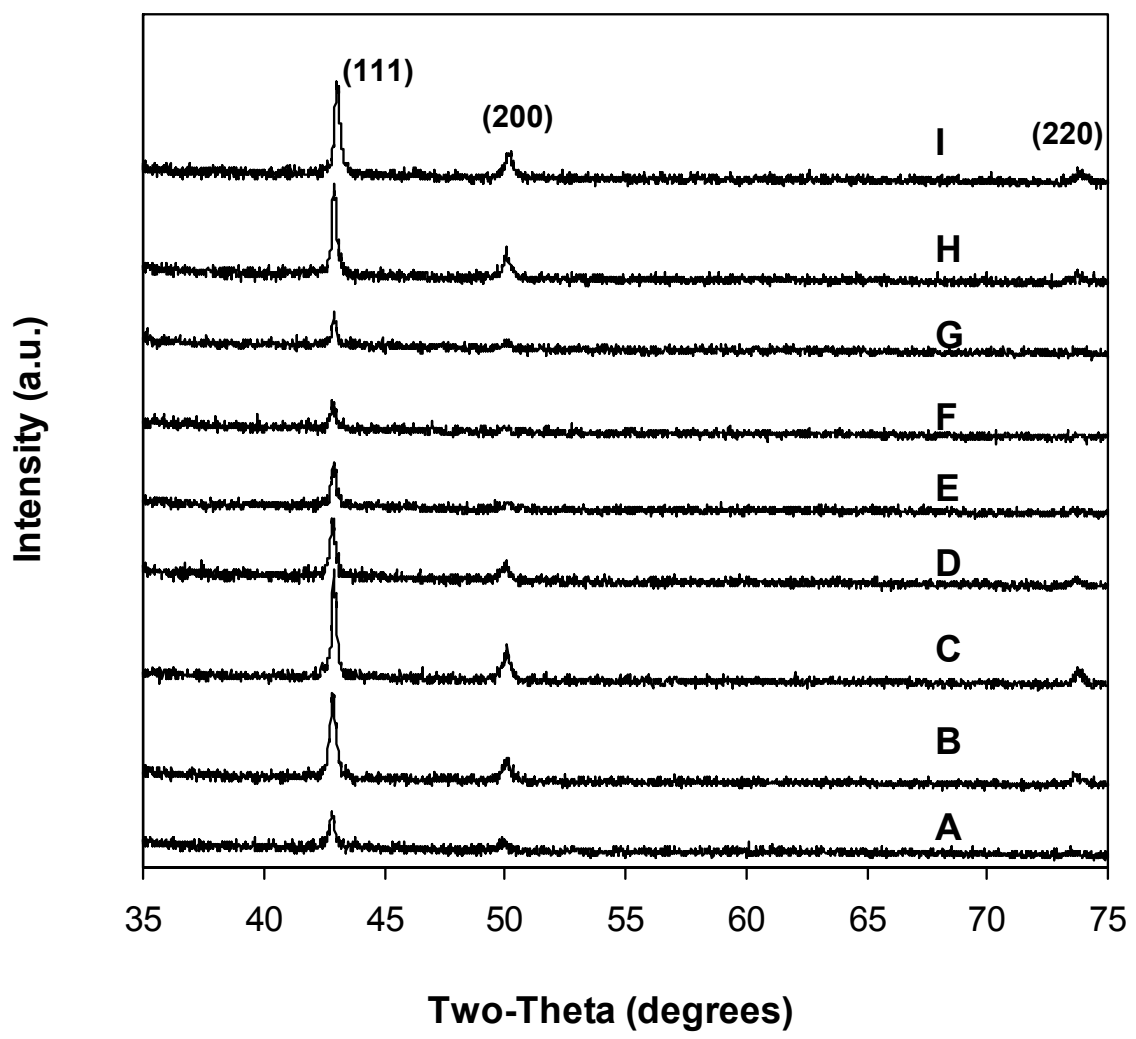

Experimental conditions for the above selected copper samples:

\begin{tabular}{|c|c|c|c|c|c|c|c|c|}
\hline \multirow[b]{2}{*}{ Expt. } & \multicolumn{2}{|c|}{$\mathrm{NaOH}$ solution } & \multicolumn{2}{|c|}{$\mathrm{Cu}\left(\mathrm{NO}_{3}\right)_{2}$ solution } & \multirow[b]{2}{*}{$\begin{array}{l}\text { Volume of } \\
\text { EDA (mL) }\end{array}$} & \multirow{2}{*}{$\begin{array}{c}\text { Volume of } \\
\mathrm{N}_{2} \mathrm{H}_{4} \\
(35 \text { wt\%) } \\
(\mu \mathrm{L})\end{array}$} & \multirow[b]{2}{*}{$\begin{array}{c}\text { Temperature } \\
\left({ }^{\circ} \mathrm{C}\right)\end{array}$} & \multirow[b]{2}{*}{$\begin{array}{c}\text { Time } \\
\text { (h) }\end{array}$} \\
\hline & $\begin{array}{c}\text { Volume } \\
\text { (mL) }\end{array}$ & $\begin{array}{l}\text { Concentration } \\
(\mathrm{Mol} / \mathrm{L})\end{array}$ & $\begin{array}{l}\text { Volume } \\
\qquad(\mathrm{mL})\end{array}$ & $\begin{array}{l}\text { Concentration } \\
(\mathrm{Mol} / \mathrm{L})\end{array}$ & & & & \\
\hline$A$ & 30 & 7.0 & 1.0 & 0.10 & 0.30 & 40.0 & 60 & 1 \\
\hline B & 30 & 7.0 & 1.0 & 0.10 & 0.35 & 40.0 & 60 & 1 \\
\hline C & 30 & 7.0 & 1.0 & 0.10 & 0.35 & 60.0 & 45 & 3 \\
\hline $\mathrm{D}$ & 30 & 7.0 & 1.0 & 0.10 & 0.35 & 70.0 & 45 & 3 \\
\hline$E$ & 30 & 7.0 & 1.0 & 0.10 & 0.40 & 40.0 & 60 & 1 \\
\hline $\mathrm{F}$ & 30 & 7.0 & 1.0 & 0.10 & 0.50 & 25.0 & 100 & 1 \\
\hline$G$ & 30 & 7.0 & 1.0 & 0.10 & 0.50 & 25.0 & 60 & 1 \\
\hline $\mathrm{H}$ & 30 & 7.0 & 1.0 & 0.10 & 0.50 & 25.0 & 60 & 3 \\
\hline I & 30 & 7.0 & 1.0 & 0.10 & 0.50 & 40.0 & 60 & 1 \\
\hline
\end{tabular}

Notes:

1) Some of the above XRD patterns have weak diffraction intensities due to a small amount of sample used in the measurement.

2) The main purpose of the above XRD measurement is to confirm the cupper phase (i.e., the diffraction peak locations). 


\section{Supporting Information 4}

A representative EDX spectrum (A) of copper nanowires (also see the SEM image $(B)$ ):
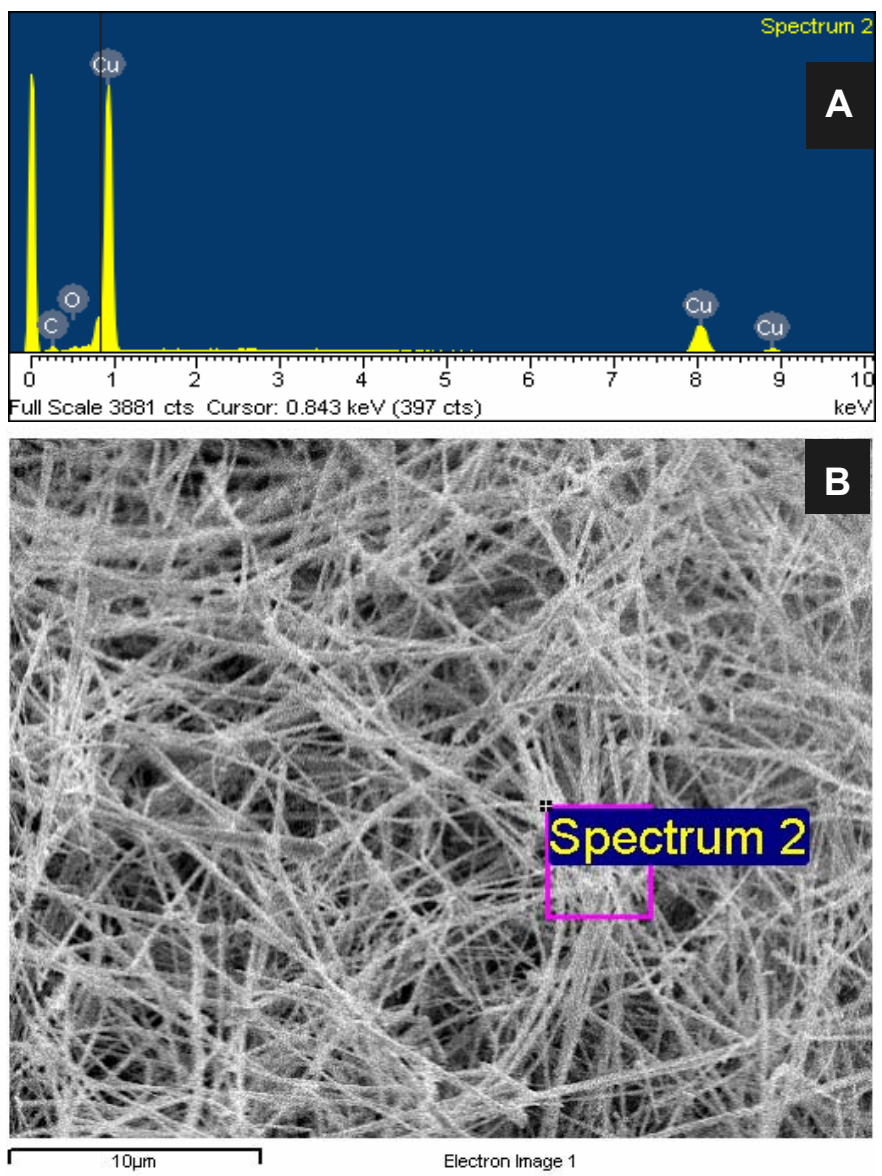

EDX analysis result of copper nanowires (Expt. A1, see SI-1)

\begin{tabular}{ccc}
\hline Element & Weight\% & Atomic\% \\
\hline C K & 9.42 & 34.49 \\
O K & 1.37 & 3.77 \\
Cu L & 89.21 & 61.74 \\
Total & 100.00 & 100.00 \\
\hline
\end{tabular}




\section{Supporting Information 5}

FESEM images of $\mathrm{Cu}$ discs synthesized with high EDA/ $\mathrm{Cu}^{2+}$ ratios (sample from Expt. B1, see $\mathrm{SI}-1)$ :
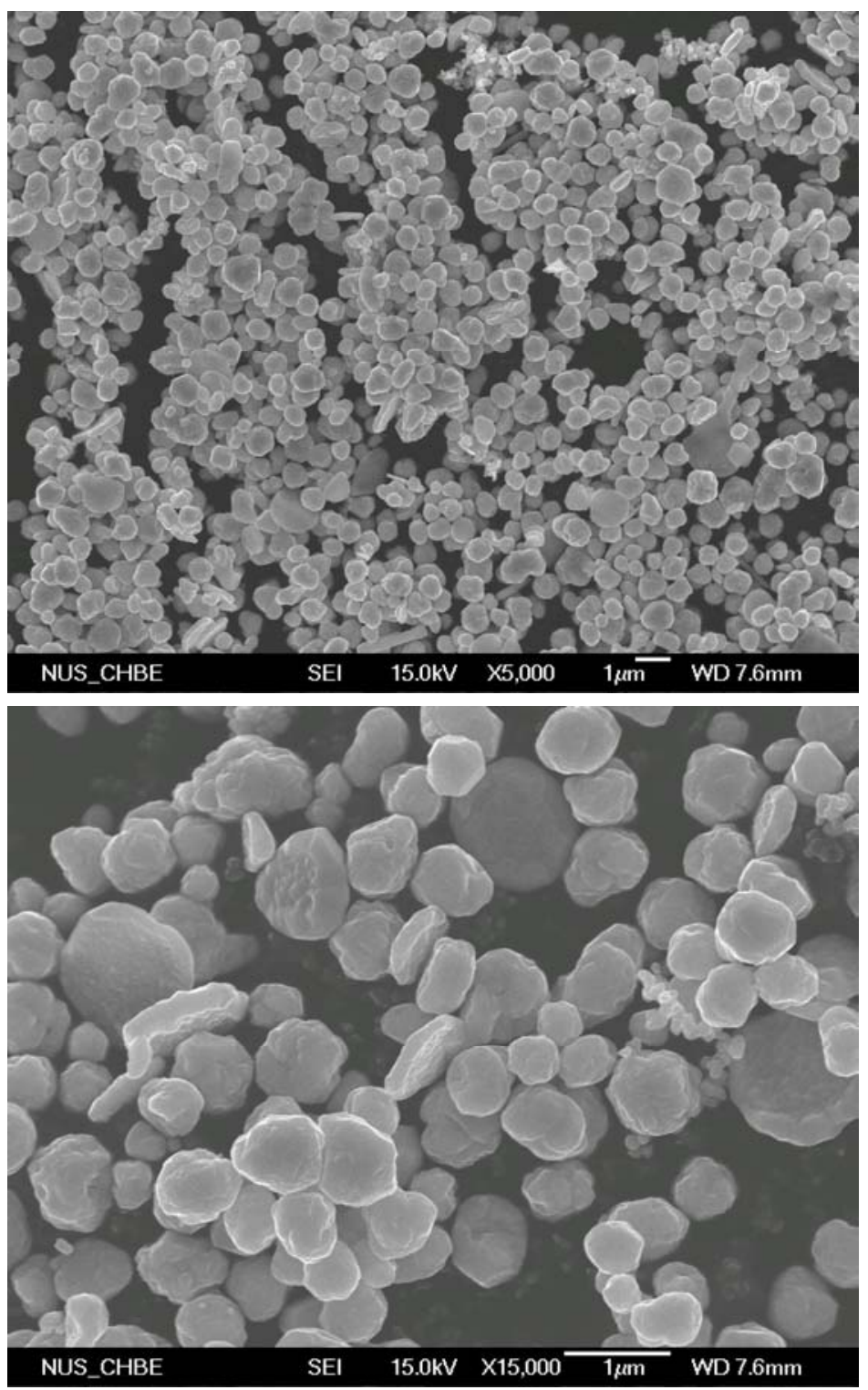


\section{Supporting Information 6}

Surface analysis of air-dried copper nanowires with XPS technique:

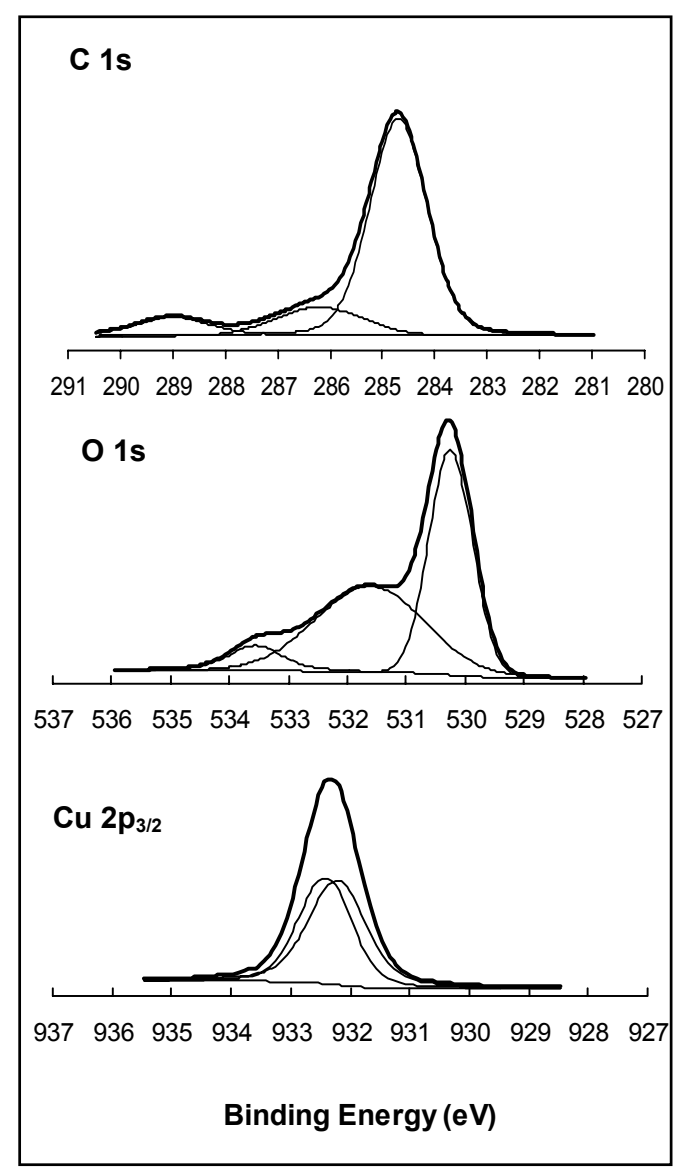

XPS spectra of $\mathrm{C} 1 \mathrm{~s}, \mathrm{O} 1 \mathrm{~s}$ and $\mathrm{Cu} 2 \mathrm{p}_{3 / 2}$ photoelectrons for sample A1 (used in Figure 4A in the main text).

Binding energies $(\mathrm{eV})$ of $\mathrm{C} 1 \mathrm{~s}, \mathrm{O} 1 \mathrm{~s}$ and $\mathrm{Cu} 2 \mathrm{p}_{3 / 2}$ photoelectrons and their relative percentage atomic ratios (indicated in parenthesis) determined from the above XPS spectra.

\begin{tabular}{cccc}
\hline \multirow{2}{*}{$\mathrm{C} 1 \mathrm{~s}$} & $\mathrm{C}-\mathrm{C} / \mathrm{C}-\mathrm{H}$ & $\mathrm{C}-\mathrm{OX}(\mathrm{X}=\mathrm{C}$ and/or $\mathrm{H})$ & $\mathrm{CO}_{3}{ }^{2-}$ \\
& $284.7(0.75)$ & $286.2(0.15)$ & $289(0.10)$ \\
\hline \multirow{2}{*}{$\mathrm{O} 1 \mathrm{~s}$} & Surface $\mathrm{Cu}_{2} \mathrm{O}$ & $\mathrm{OH}^{-}$and $\mathrm{CO}_{3}{ }^{2-}$ & $\mathrm{H}_{2} \mathrm{O}$ \\
& $530.2(0.47)$ & $531.6(0.45)$ & $533.5(0.08)$ \\
\hline \multirow{2}{*}{$\mathrm{Cu} 2 \mathrm{p}_{3 / 2}$} & $\mathrm{Cu}$ & $\mathrm{Cu}_{2} \mathrm{O}$ & \\
\hline
\end{tabular}

Notes: 1) The presence of $\mathrm{CO}_{3}{ }^{2-}$ is due to the atmospheric $\mathrm{CO}_{2}$ adsorption.

2) With a prolonged oxidation of copper nanowires, $\mathrm{CuO}$ phase can also be detected.

3 ) The above $\mathrm{Cu} 2 \mathrm{p}_{3 / 2}$ assignments have also been verified with Auger electron spectra (Cu $\left.L_{3} V V\right)$. 


\section{Supporting Information 7}

$\mathrm{XRD}$ investigation on air oxidation of copper nanowire with various reaction times at $300^{\circ} \mathrm{C}$ :

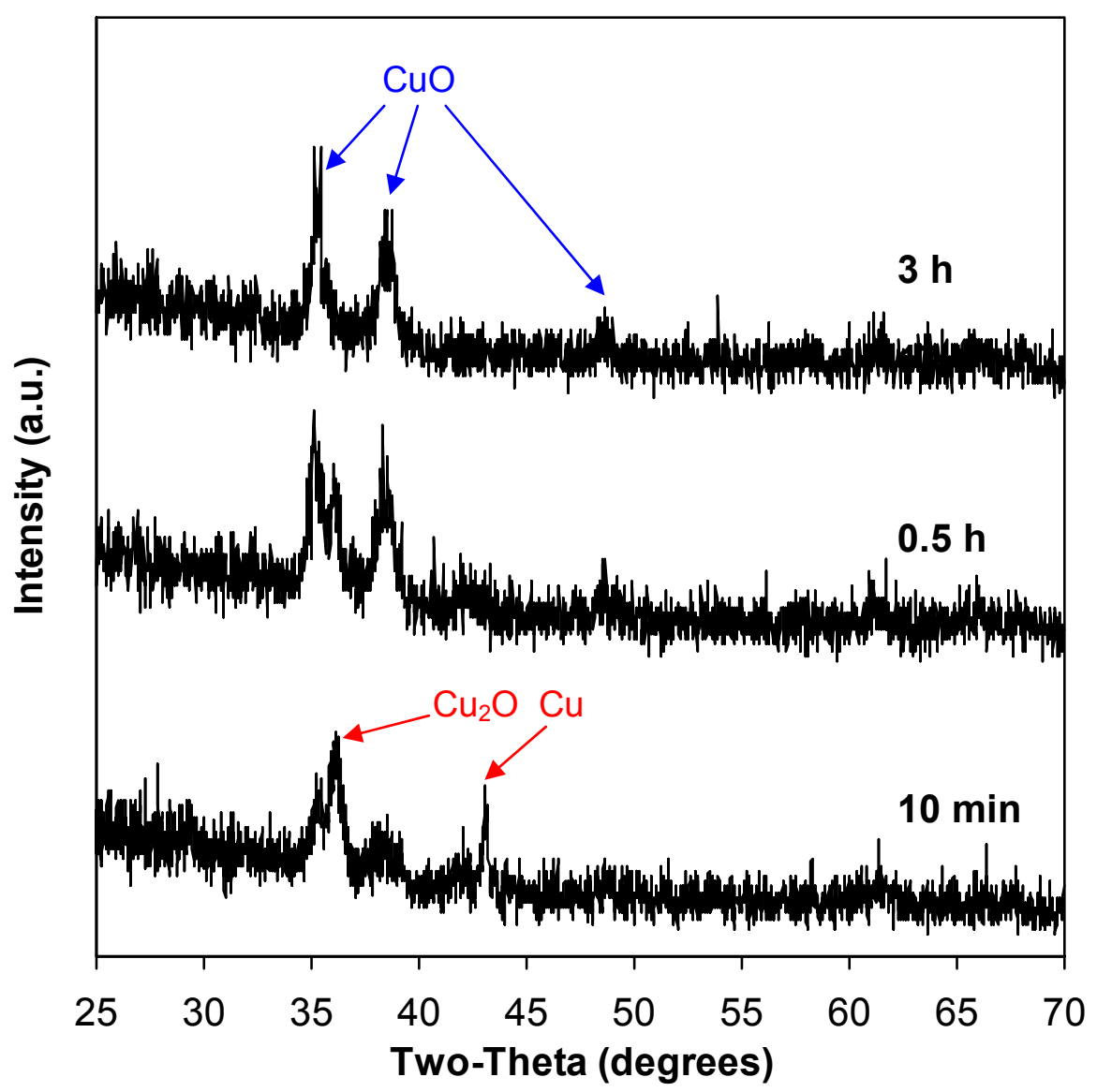

